\title{
Unknown agents in translated political discourse
}

\author{
Christina Schäffner \\ Aston University
}

\begin{abstract}
This article investigates the role of translation and interpreting in political discourse. It illustrates discursive events in the domain of politics and the resulting discourse types, such as jointly produced texts, press conferences and speeches. It shows that methods of Critical Discourse Analysis can be used effectively to reveal translation and interpreting strategies as well as transformations that occur in recontextualisation processes across languages, cultures, and discourse domains, in particular recontextualisation in mass media. It argues that the complexity of translational activities in the field of politics has not yet seen sufficient attention within Translation Studies. The article concludes by outlining a research programme for investigating political discourse in translation.
\end{abstract}

Keywords: political discourse, political institution, recontextualisation, Critical Discourse Analysis, agency

\section{Introduction}

Since 2011, the European Union has been experiencing an economic and financial crisis. At a series of meetings, EU politicians have discussed potential solutions and have proposed rescue packages. Their debates have led to the drafting and/ or signing of agreements, treaty amendments, fiscal compacts and other kinds of policy documents. Politicians regularly comment on their decisions, for example in debates in their own national parliaments, in speeches to their own citizens, or at press conferences to representatives of the national or international mass media. The mass media play a significant role in communicating politics to the general public, by reporting about political events, by interviewing politicians, by broadcasting press conferences on TV, etc. An illustrative example in the context of the EU's financial crisis is a bilateral meeting of the French President Nicolas Sarkozy and the German Chancellor Angela Merkel, held on 16 August 2011 in 
Paris. One of the outcomes of this meeting was a joint letter addressed to Herman van Rompuy, the President of the European Council, in which they outlined proposals for a system of economic governance. The two politicians also gave a joint press conference, at which they presented their proposal and answered journalists' questions. TV and radio channels as well as news agencies reported this meeting on the same day, with subsequent articles published by the mass media during the days following.

Political meetings and press conferences are typical discursive events in the domain of politics, and these events lead to policy statements, political letters, and reports as examples of political discourse. Scholarly interest in the link between language and politics resulted in the development of Political Linguistics which encompasses research into the language of politics and into the politics of language, using a variety of analytical methods (e.g. the contributions in Okulska and Cap 2010). Some analyses of political communication have been conducted within Critical Discourse Analysis (e.g. Fairclough 1995, 2006; Weiss and Wodak 2003; Wodak and Chilton 2005) and have resulted in the identification of patterns of language in use in particular political settings, i.e. language and discursive practices. The shared assumptions are that language is a social phenomenon, and that language and political actions are closely intertwined, or, as Chilton (2004:6) says "political activity does not exist without the use of language".

In an increasingly globalised world, politics too is increasingly international in nature. Political decisions can hardly affect only a small local community, and political actors often need to explain and justify their decisions to an international audience. Communicating across national borders involves communicating across languages, which also means that very frequently translation and interpreting play a significant role in political settings. For example, extracts from the joint press conference by Sarkozy and Merkel mentioned above were shown on the British TV channel BBC, with voice-over in English for Merkel's German and Sarkozy's French statements. UK mass media reported on the meeting and the press conference the following day, including quotes from the two politicians, presented in English, in their articles. The joint letter to van Rompuy was made available in French, German, and English. The analysis of such examples of political discourse is thus also of interest to scholars within Translation Studies, as is the investigation of the discursive events in which such discourse emerged.

So far, however, the investigation of political discourse in translation has been underexplored in the discipline of Translation Studies. There are a number of case studies of translated political texts which identified translational shifts and were thus text-centred (e.g. Calzada Pérez 2001; Baumgarten and Gagnon 2005). Other research investigated aspects such as censorship and translation policies under totalitarian regimes (e.g. the contributions in Rundle and Sturge 2010) or the role 
of translators and interpreters in conflict situations (e.g. Baker 2006; Boéri and Maier 2010), thus also focusing on the politics of translation. News translation and the practices of news agencies have recently received more attention (e.g. Bielsa and Bassnett 2009), whereas translation policies and practices in political institutions at national and supra-national level have rarely been addressed (but see, for Canada, Mossop 1990 and Gagnon 2010, for the EU institutions, Koskinen 2000, 2008). Much remains to be investigated in order to get a deeper insight into political discourse in translation and the institutional practices and policies which determine it.

In this article, I will show why political texts, such as joint letters, and political events, such as press conferences, are of interest to Translation Studies. The Merkel-Sarkozy meeting mentioned above will be used to provide a coherent link from one discursive event to the next, thus also showing the interrelations between the political genres in processes of recontextualisation. The order in which the examples have been arranged reflects the increasing complexity of the discursive event in respect of translation and/or interpreting: jointly produced texts, press conferences and speeches. Each section will illustrate some findings of the analysis and will also list a number of questions for future research. At the end of the article, I will sketch a research programme for investigating political discourse in translation.

\section{Jointly produced texts: A common voice?}

The types of political discourse which resulted from the Sarkozy-Merkel meeting are a joint letter, statements, and a press conference. What they have in common is that they were initiated in political institutions and that political actors are the main discourse agents. Fairclough $(1995,2000)$ speaks of 'orders of discourse' to denote the totality of discursive practices and the interrelated institutional types of discourse of a social domain. The discourse types can be in relationships of complementarity, inclusion/exclusion, or opposition, which lead to forms of intertextuality, interdiscursivity, recontextualisation. There is complementarity of the discourse types of the joint letter and the press conference in that both Sarkozy and Merkel explicitly refer to this letter in their introductory statements, as can be seen in the extracts below: ${ }^{1}$

(1) Sarkozy: [...] Nous avons donc décidé d'un certain nombre de propositions communes qui feront l'objet d'une lettre franco-allemande qui sera adressée, dès demain matin, au Président VAN ROMPUY. [...] 
BK'IN MERKEL: [...], wir hatten bereits am 21. Juli angekündigt, dass wir im Verlaufe des August Vorschläge unterbreiten werden, wie die Eurozone enger zusammenarbeiten kann. Diese Vorschläge werden wir Herman Van Rompuy auch in einem Brief mitteilen, so wie es soeben der französische Präsident, Nicolas Sarkozy, gesagt hat. [...]

In Merkel's extract we see intratextual reference to Sarkozy's preceding statements, as well as a reference to proposals which had been arrived at during an earlier meeting in July. These references add to the complementarity and intertextuality of the discourse. Both government websites have hyperlinks to the full text of the joint letter. Although this letter is identified as a joint French-German letter, it was produced in French, German, and English. Both the French and the German text start with a form of address (Sehr geehrter Herr Präsident, Monsieur le Président $d u$ Conseil européen,) and finish with the conventional greetings (Mit freundlichen Grüßen; Nous vous prions d'agréer, Monsieur le Président, l'expression de notre haute consideration), followed by the names of the two politicians. The English version of the letter is just entitled 'Letter to President van Rompuy' and does not include any conventional opening and closing formulas.

These differences in the letter conventions could be explained with reference to the authorship: two politicians representing different countries write a joint letter to another politician. In addition, the joint letter is also meant to be read by other politicians and the general public in both France and Germany, and also in other EU member states. As a Belgian citizen, van Rompuy can be expected to understand French, which means that the addition of an English version of the letter reflects political considerations and the wider readership. Joint French-German proposals which are meant to have an effect on the euro-zone as a whole are thus not solely addressed to van Rompuy as the main addressee but equally to other EU politicians (and also journalists) as auditors.

If we compare the three language versions of the letter we note some interesting features which raise questions for Translation Studies. I will just give three illustrative cases: differences in the use of metaphorical expressions, of interpersonal relationships, and of EU-specific terminology (emphasis mine).

(2) a. [...] Diese Treffen [...] dienen als Eckpfeiler der verbesserten wirtschaftlichen Steuerung des Euro-Währungsgebiets. [...] Auf diesen Gipfeltreffen werden [...] die Eckpfeiler der dortigen Wirtschaftspolitik definiert, $[\ldots]$

b. [...] Ces sommets constitueront la pierre angulaire du nouveau gouvernement économique de la zone euro. Ces sommets [...] permettront [...] de définir les principales orientations de la politique économique $[\ldots]$ 
c. Regular meetings of the euro area Heads of State and Government: these meetings will be convened twice a year [...] to act as the cornerstone of the enhanced economic governance of the euro area. [...] These summits will also [...] define the main orientations of the economic policy [...]

The German text uses the metaphorical expression Eckpfeiler twice, whereas both the French and the English text have a metaphorical expression first (pierre angulaire, cornerstone), followed by a non-metaphorical formulation in the second case. In respect of the interpersonal relations, we note the formal vous in French but the informal $d u$ in the German version, cf:

(3) a. Wir haben unserem Wunsch Ausdruck verliehen, dass $D u$ diese Aufgabe übernimmst. [...] Schließlich wollen wir Dich davon in Kenntnis setzen, [...]

b. Nous avons exprimé notre souhait que vous puissiez assumer cette charge. [...] Enfin, nous tenions à vous informer [...]

c. We expressed our wish that you could take on this job. [...] Finally, we wish to inform you [...]

The key idea of the new joint proposal is expressed by gouvernance and governance in the French and the English texts, but by more complex phrases in German, cf.:

(4) a. [..] schlagen Frankreich und Deutschland vor, die wirtschaftspolitische Steuerung des Euro-Währungsgebiets in Übereinstimmung mit den bestehenden Verträgen weiter zu stärken.

1/ Steuerung des Euro-Währungsgebiets stärken

b. [...] la France et l'Allemagne proposent de renforcer encore la gouvernance de la zone Euro, dans le cadre des traités existantes. 1/ Renforcement de la gouvernance de la zone Euro

c. [...] France and Germany propose to strengthen further the governance of the euro area, in line with existing treaties.

$1 /$ Strengthening the governance of the euro area

These differences may look trivial, but for a Translation Studies scholar they raise the question: how were these three texts produced? Was one text produced first and then translated into the other two languages? Or were the joint discussions conducted in French and German and was the English text produced subsequently? With reference to the metaphorical expressions and the terminology in the extracts above, there is more similarity between the French and English texts which could lead to the hypothesis that the English text was translated from the French one. 
This joint letter was discussed at the meeting and probably before as well, but only made publicly available after the conclusion of the meeting. Discussions between the two leaders and also between their political advisors are other examples of discourse types which contribute to the order of discourse in the domain of politics.

At the beginning of the joint press conference, the French President Sarkozy explicitly referred to these complex and multiple discussions, cf.:

(5) a. Sarkozy: [...] Pour tout dire, nous avons travaillé d'arrache-pied, pas simplement cet après-midi mais tous ces jours derniers, pour présenter des propositions communes ambitieuses.

Such discussions 'behind closed doors' are not normally communicated verbatim to the general public. Press conferences, however, are primarily intended for informing representatives of the mass media, and by extension the general public, of political debates held and decisions reached. In fact, Bhatia (2006: 176) characterizes press conferences as "mediatization of political action". It has become a frequent practice that complete transcripts of press conferences are made available on websites of political institutions. In the next section I will illustrate why such transcripts are of interest to Translation Studies.

\section{Press conferences: Whose voice is heard?}

Press conferences normally start with statements by the politicians, followed by a question and answer session which gives the journalists the chance to explore certain issues further. The Sarkozy-Merkel press conference was a bilingual event, with the two politicians using exclusively their mother tongues, French and German, respectively. This can be verified by watching a video which can be accessed via a link on the French website. Simultaneous interpreting was used throughout, both for the politicians themselves and for the journalists. The transcripts of this press conference are available in French only on the website of the French government and in German only on the website of the German government. This indicates that translational actions have been involved in turning the spoken discourse of the press conference into a written text for the website. Sarkozy's introductory comments (see 5a) read as follows on the website of the German government:

(5) b. P SARKOZY:[...] Ich möchte hier ausführen, dass wir wirklich sehr hart gearbeitet haben, nicht nur heute Nachmittag, sondern auch in den letzten Tagen, um gemeinsame Vorschläge zu unterbreiten, die sehr ambitiös gestaltet sind. 
This German text is syntactically more complex than the French: the French adjectival phrase (propositions communes ambitieuses) has been rendered by a relative clause (gemeinsame Vorschläge ... die sehr ambitiös gestaltet sind). Moreover, the German text is slightly more emphatic than the French as a result of the addition of wirklich (we have worked very hard indeed). There is no explicit reference to interpreting and/or translation in the French transcript. The website of the German government has a sentence at the very beginning, saying that the transcript of the non-German text is based on the simultaneous interpreting (Die Ausführungen des fremdsprachlichen Teils erfolgten anhand der Simultanübersetzung). This is the standard sentence we usually find for transcripts of press conferences on the website of the German government, although translation and interpreting have been mixed up (simultaneous translation is used). This is also confirmation that the typical practice seems to be to recontextualise the oral rendition produced by the interpreter instead of producing a subsequent translation of the statements. Some minor grammatical and stylistic enhancement does take place in this process, and incomprehension is explicitly indicated as well (as indistinct, or akustisch unverständlich), as my analysis of press conferences so far has revealed (Schäffner 2010, 2012).

As mentioned above, there is intertextuality between the press conference and the joint letter. If we compare the French and the German transcripts of the press conference, there is an interesting case of terminological inconsistency, which links back to example (4) above. In his statement at the press conference, Sarkozy introduces the proposals to be put forward to van Rompuy as follows (emphasis mine):

(6) a. La première de ces propositions consiste à instaurer dans la zone euro un véritable gouvernement économique de la zone euro. Ce gouvernement économique sera constitué du Conseil des chefs d'Etat et de gouvernement.

The text on the German website reads as follows:

(6) b. Der erste dieser Vorschläge besteht darin, eine wirtschaftspolitische Steuerung der Eurozone vorzusehen. Diese Wirtschaftsregierung besteht aus den Staats- und Regierungschefs.

As we saw in extracts (4) above, gouvernance de la zone Euro and wirtschaftspolitische Steuerung des Euro-Währungsgebiets, respectively, were used in the official versions of the joint letter. At the press conference, Sarkozy did not use gouvernance at all but referred consistently to gouvernement économique. Merkel herself did not use wirtschaftspolitische Steuerung, and Wirtschaftsregierung either. Although simultaneous interpreting into German was provided for Merkel (and 
journalists), these words are not readily available from the video on the French website. A comparison of the interpreter's German rendition and the text on the German government's website is thus not possible. The question therefore is: why have the two occurrences of the same French term (gouvernement économique) in immediate vicinity been rendered differently into German? An answer to this question cannot be provided, but going beyond this specific text and including related discourse types can at least result in some hypotheses.

The English version of the joint letter had used governance of the euro area to render gouvernance de la zone Euro, which on the surface is a more direct equivalent phrase compared to the somewhat clumsy German wirtschaftspolitische Steuerung des Euro-Währungsgebiets. This concept had already been used in texts before the meeting in August 2011, for example in a previous joint Franco-German Declaration, adopted in Deauville, France, on 18 October 2010, and also made available in French, German, and English. In this declaration we read (emphasis mine):

(7) a. Le France et l'Allemagne sont d'accord sur la nécessité de renforcer le gouvernement économique européen.

http://www.elysee.fr/president/les-actualites/declarations/2010/ declaration-franco-allemande.9870.html

b. Deutschland und Frankreich sind der Auffassung, dass die europäische wirtschaftspolitische Zusammenarbeit gestärkt werden muss. http://www.alexander-alvaro.de/wp-content/uploads/2010/10/deauville18-10-2010-dt.pdf

c. France and Germany agree that the economic governance needs to be reinforced.

http://www.elysee.fr/president/root/bank_objects/Franco-german_ declaration.pdf

We can see that gouvernement économique had already been used in the French text, whereas the German text opted for lexical variation (economic cooperation). The more immediate German equivalent Wirtschaftsregierung had been avoided. In fact, German politicians had repeatedly argued that what was needed for the eurozone was not a government with power and structures, but rather some agreed form of regulation and checking. In an interview which the German news magazine Der Spiegel conducted with the German Finance Minister Wolfgang Schäuble in August 2011, a few days before the Sarkozy-Merkel meeting, Schäuble too stressed the need to maintain national financial policies despite having the euro as a common currency. He added:

(8) a. Und an der weiteren Verbesserung des Krisenmanagements und der sogenannten Governance in der Euro-Zone arbeiten wir ja gerade. (Der Spiegel, 15 August 2011, p. 28) 
This was rendered into English as

(8) b. [...] and we're working to further improve crisis management and eurozone governance.

(Spiegel International, 15 August 2011, http://www.spiegel.de/ international/europe/0,1518,780248,00.html

In the original German text, Schäuble had actually referred to the so-called governance, thus reflecting an awareness of the problematic issue of finding an appropriate label for new forms of supra-national coordination of policies. At a press briefing of the German government held on 15 August 2011, the government spokesman Steffen Seibert informed the journalists present of the Sarkozy-Merkel summit and the topics to be discussed, also mentioning that joint proposals were to be sent to van Rompuy. The transcript of this press briefing quotes Seibert as follows:

(9) [...] Es geht darum, gemeinsame Vorschläge zur Stärkung der wirtschaftspolitischen Steuerung der Eurozone zu erarbeiten. [...]

(Literally: The task is to draft joint proposals for strengthening the economic control/coordination of the euro-zone [...]

In response to a question, whether speaking of wirtschaftspolitische Steuerung meant that working towards a common financial policy would explicitly be ruled out, Seibert replied:

(10) Wenn Sie so wollen, geht es, um dieses Wort „Governance“, das immer in der Luft schwebt, einmal einigermaßen sinnvoll ins Deutsche zu übersetzen, darum, eine weitergehende wirtschafts- und finanzpolitische Steuerung, eine Verbesserung der wirtschaftspolitischen Steuerung zu finden.

(Literally: If you like, and to find a somewhat meaningful German translation for the word 'governance' that is always used so vaguely, the task is to find a more extensive economic and financial control, an improvement of the economic control.)

http://www.bundesregierung.de/Content/DE/Mitschrift/ Pressekonferenzen/2011/08/2011-08-15-regpk.html?nn=430000

These extracts confirm that there was some unease amongst German politicians about using Wirtschaftsregierung and the attempt to agree on an appropriate German term. It may well be that the interpreter at the Sarkozy-Merkel meeting was aware of the debates about terminology and of the attempt of the German government to have wirtschaftspolitische Steuerung accepted in official documents, which led to the rendering in (6b). Another hypothesis to explain the discrepancy in Sarkozy's words at the press conference and the text in the joint letter could be that 
the French side had agreed to replace gouvernement économique in an earlier draft of the letter by gouvernance de la zone Euro, in response to the debates (and as a gesture to the German side?). An article in Le Figaro lends support to this hypothesis since we read (emphasis mine):

(11) Dans une lettre qui sera adressée mercredi à la présidence de l'Union européenne, France et Allemagne proposent de créer un «gouvernement économique de la zone euro"

(Le Figaro, 16 August 2011

http://www.lefigaro.fr/conjoncture/2011/08/16/04016-

20110816ARTFIG00420-sarkozy-et-merkel-veulent-un-gouvernementpour-l-europe.php

If this were the case, the analysis of the various texts and their renderings into other languages also provides insights into the dynamics of discursive events. It is interesting to see that at a recent press conference held by Sarkozy and Merkel in Paris on 6 February 2012, Sarkozy did use gouvernance économique which was rendered again into German as wirtschaftspolitische Steuerung.

This whole debate about terminology is of course not pure semantics, but reveals political interests and worries. With respect to 'economic governance', the mass media had already repeatedly commented on different interpretations between the French and German politicians. When the proposal came up again at the Sarkozy-Merkel meeting in August 2011, the British weekly magazine The Economist commented as follows in an editorial:

(12) [...] stronger euro-zone economic governance [...] [These measures] constitute a step towards political union. That is what airy labels like "economic government" or "deeper integration" actually mean.

(The Economist, 20 August 2011, p. 10-11)

Complete texts written by politicians or complete transcripts of press conferences are not the most typical form of political discourse in the mass media. Mass media produce texts within their own media institutions, thereby also engaging with political events and political discourse, as example (12) shows. Journalistic texts are thus also in intertextual relations with political texts, which, moreover, can be relations of intertextuality across languages and cultures. In the next section I will illustrate what kind of questions journalistic practices of text production can pose for Translation Studies. 


\section{Recontextualisation of political discourse in mass media across languages}

In the section above, I have shown aspects of complementarity of the discourse types, joint letter and press conference. Relationships of complementarity or opposition between and across social domains are particularly obvious in the domains of politics and media. That is, institutional types of discourse in the domain of politics, such as speeches and press conferences, are closely linked to types of media discourse, such as editorials, comments, and news. Media texts draw upon, reorganise, and transform different discourses in constructing political events, with omission, addition, and rephrasing as typical transformation strategies (e.g. Blackledge 2005). Such processes of recontextualisation have been investigated in Critical Discourse Analysis, and there is plenty of evidence that mass media are not neutral reporters, but that they actively construct and shape representations of politics as a result of the way they select and structure their discourse (e.g. Conboy 2007; Patrona 2011). Le (2010:185) therefore characterizes newspapers as "political actors".

Discourse produced at the Sarkozy-Merkel meeting was recontextualised in mass media mainly in shorter and amended form. For example, German and French newspapers incorporated direct quotes from the joint letter (emphasis mine, indicating links to extract 3):

(13) Deshalb sehen Merkel und Sarkozy in Van Rompuy den neuen Chef der Eurogruppe und bitten in einem Brief, „dass Du diese Aufgabe übernimmst“. (Der Tagesspiegel, 22 August 2011 http://www.tagesspiegel.de/wirtschaft/neues-gesicht-alte-probleme/4528826. html

(14) Dans cette lettre, M. Sarkozy et $M^{\text {me }}$ Merkel écrivent au président de l'UE que les dix-sept « chefs d'Etat et de gouvernement de la zone euro éliront un président pour un mandat de deux ans et demi », poursuivant: " nous avons exprimé notre souhait que vous puissiez assumer cette charge». Ils affirment également $[\ldots]$ que «l'euro est le fondement de notre réussite économique et le symbole de l'unification politique de notre continent ». (Le Monde, 17 August 2011 http://www.lemonde.fr/economie/article/2011/08/17/le-couple-francoallemand-souhaite-suspendre-des-fonds-structurels-aux-pays-qui-nebaissent-pas-leurs-deficits_1560585_3234.html

In these cases it seems logical to assume that the journalists used the German and French versions of the letter as a reference point for their texts. However, English language mass media, too, commented on the meeting and the letter, also incorporating direct quotes into their articles, as can be seen in the extract below: 
(15) "The euro is the foundation of our economic success and the symbol of the political unification of our continent," the zone's two most powerful leaders said, in a joint statement drawn up after they held talks on Tuesday. "France and Germany propose to reinforce once more the governance of the eurozone within the framework of existing treaties," they wrote, proposing that eurozone leaders elect a president for a two-and-a-half year mandate. "We have expressed our hope that you could assume this role," they added. (EUbusiness, 17 August 2011

http://www.eubusiness.com/news-eu/finance-economy.btc

The direct quotes provided by EUbusiness, which presents itself as "an independent online business information service about the European Union", are not identical to the English version of the joint letter. This official English version of the letter says: The Euro is the basis of our economic success and symbol for the political unification of our continent, France and Germany propose to strenghten (sic) further the governance of the euro area, in line with existing treaties, and [w] expressed our wish that you could take on this job. Although the differences are minor, this aspect leads to the hypothesis that the journalist used either the French or the German text as a source for producing their own English text.

In reporting the press conference, English-speaking mass media again incorporated direct quotes in their own evaluative articles, as illustrated in the two shortened extracts below:

(16) a. The French and German leaders have called for "true economic governance" for the eurozone in response to the euro debt crisis.

[...] Ms Merkel [...] "We will regain the lost confidence," she said. "That is why we go into a phase with a new quality of co-operation within the eurozone."

(BBC News, 16 August 2011

http://www.bbc.co.uk/news/business-14549358

(17) a. Merkel "[...] I think that what we are proposing here is the means with which we can solve the crisis right now and win back trust, step by step [...]"

The French president said that the aim was to create a "real economic government for the eurozone", made up of heads of state and government, which would meet at least twice a year.

(The Guardian, 17 August 2011, http://www.guardian.co.uk/ business/2011/aug/17/angela-merkel-nicolas-sarkozy-summit

In these extracts, both Merkel and Sarkozy are quoted in direct speech and in English, although at the press conference, they were actually speaking in German and in French, respectively. Using direct quotes is a common feature of journalistic 
writing which has also been studied in Critical Discourse Analysis. For example, Li (2009) argues that quotations by political actors are never simple citations but involve (re)interpretations of events and power relations. The selection of quotations for inclusion in journalistic articles is also a process of redefining power structures, since certain political actors can be empowered whereas others can be silenced.

Direct quotes in journalistic discourse pose a challenge for Translation Studies as well. In addition to the quantitative aspect (i.e. the question of whose voice is heard more often in a journalistic text), the way direct and reported speech is combined can also contribute to the positioning and construction of the political actors. Since complete transcripts of the Sarkozy-Merkel press conference are available in French and in German on the government websites, German and French media wishing to quote the politicians directly can make use of them. Foreign language journalists too can refer to the transcripts as a source for producing their own language version, although the processes become more complex if they actually use a translation (or the transcript of the interpreting) as their source. The direct quotes in extracts (16) and (17) come from the statements at the beginning of the press conference and they were shortened to fit the new syntactic and textual environment. The German government website presents Merkel's exact words as follows:

(16) b. Durch beständiges und vor allen Dingen auch nachvollziehbares und abrechenbares Arbeiten wird dieses Vertrauen wiedergewonnen werden. Dazu legen wir qualitativ eine neue Phase in der Zusammenarbeit in der Eurozone ein.

(Literally: As a result of persistent and above all recognisable actions which we can be held accountable for, this trust will be regained.

Therefore we start a qualitatively new phase of co-operation within the eurozone.)

This was rendered into French as follows for the transcript on the website of the French government:

(16) c. [...] mais nous sommes convaincus que par une action permanente et grâce à un travail de fond, nous pourrons reconquérir cette confiance. C'est la raison pour laquelle, nous passons à une nouvelle phase qualitative de coopération au sein de la zone euro.

The shortening of Merkel's text has also resulted in another syntactic change: both the $B B C$ and The Guardian turned the passive structure into active voice (We will regain the lost confidence, we can solve the crisis right now and win back trust note the different degree of certainty in will vs can). Active voice can be seen in the 
French version as well, albeit somewhat hedged by the modal verb (nous pourrons reconquérir cette confiance). Judged by these structural similarities, it could well be that the British journalists used the French text as the basis for their own reports.

The direct quote by Sarkozy in extract (17) reflects the more literal real economic government for the eurozone for Sarkozy's véritable gouvernement économique which he had used at the press conference, and discussed above. Since at the August 2011 meeting only German and French were used at the press conference, it remains an open question how the English journalists produced the quotes for their English texts. They might have been present at the press conference, understanding French and/or German themselves, or they may have had the transcripts translated into English. In any case, translation processes were involved in the production of the texts which were published in the mass media. I will give one more example which illustrates that recontextualisation of political discourse can be even more complex.

On 7 and 8 June 2011, the German Federal Chancellor Angela Merkel was in Washington to receive the Presidential Medal of Freedom from President Barack Obama. This state visit saw several interrelated discursive events with their respective discourse types: speeches by both politicians at a welcoming ceremony and at a state dinner at which the medal was presented, a joint press conference, and official meetings outside the public domain. Simultaneous interpreting was provided at the press conference, and consecutive interpreting for the speeches at the two other events. The texts of Merkel's two speeches are available in both German and English on the website of the German government, as is a transcript in German of the press conference. The website of the White House has transcripts in English only of the press conferences, and the speeches by both Obama and Merkel also in English only. Merkel's speeches have 'as translated' written in brackets after her name.

A comparison between the English versions of Merkel's speeches on the German and the White House websites show differences, even if only of a minor nature. I will just give one example below. Merkel started her speech at the State Dinner by referring to her own life and her dreams of travelling to the USA once she had reached retirement age, cf.:

(20) a. Ich bin im unfreien Teil Deutschlands, der DDR, aufgewachsen. Viele Jahre habe ich, wie viele, viele andere, von Freiheit geträumt - auch von der Freiheit, in die USA zu reisen. Ich hatte mir das sehr fest vorgenommen für den Tag, an dem ich das Rentenalter erreiche; das lag bei Frauen in der DDR bei 60 Jahren, bei Männern erst bei 65 Jahren so waren wir als Frauen privilegiert. (http://www.bundesregierung.de/nn_1498/Content/DE/ Rede/2011/06/2011-06-07-usa-medal-of-freedom.html) 
The English version of this speech as available on the website of the German government is a fairly literal translation, even reproducing the dashes in the same position:

(20) b. I grew up in the part of Germany that was not free, the German Democratic Republic. For many years I dreamed of freedom, just as many others did - also of the freedom to travel to the United States. That was what I planned to do on the day I reached retirement age, which was 60 for women in the GDR, but 65 for men - so we women were privileged. (http://www.bundesregierung.de/nn_6566/Content/EN/ Reden/2011/2011-06-15-chancellor-washington-medal-of-freedom. html)

The English translations of Merkel's speeches on the German website are not explicitly indicated as advance translation, nor are the German versions accompanied by the statement Es gilt das gesprochene Wort, which is the equivalent to 'check against delivery'. The transcript available on the website of the White House Office of the Press Secretary reads as follows:

(20) c. I grew up in the part of Germany that was not free, the German Democratic Republic. For many years, I dreamt of freedom, just as many others did. Also of the freedom to travel to the United States. And I already had planned this out for the day that I would reach retirement age. That was the age of 60 for men - sorry, for women at the time, and 65 for men. So we as women were somewhat privileged at the time. (Laughter) (http://www.whitehouse.gov/the-press-office/2011/06/07/remarkspresident-obama-and-chancellor-merkel-exchange-toasts)

Whereas Merkel was reading out the prepared text (as can be seen in the video of this discursive event available on the White House website), the interpreter (not visible in the video) definitely did not do so, even if an advance translation might have been given to her before. The text in (20c) shows features of oral speech (e.g. beginning a sentence with and, the more colloquial planned this out, and the explicitation the day that I would reach). The other noticeable feature is a slip of the tongue of the interpreter, which she corrected immediately. The transcript on the White House website indicates laughter at the end of this turn, which makes one wonder whether the impression which the audience got was that Merkel had corrected an error she had made herself.

These transcripts are put on the White House website immediately after the event, as can be seen by the indication of 'For Immediate Release' at the top of each 
transcript, and by the addition of the time of beginning and end of each discursive event (the texts on the German government website do not provide this information). Due to this immediacy of the release into the public domain, it seems that no proof-reading, correction, and authorisation has happened. What is interesting, however, is that in reporting about this event, USA Today copied verbatim this very extract from Merkel's speech for inclusion in an article the next day, indicating it as a direct quote:

(20) d. [...] reach retirement age. That was the age of 60 for men - sorry, for women at the time, and 65 for men. So we as women were somewhat privileged at the time...

(USA Today, 8 June 2011

(http://content.usatoday.com/communities/theoval/post/2011/06/ obama-pays-tribute-to-merkel/1).

Although the article was published one day after the speech had been delivered, obviously the journalist had not become (or been made) aware of the fact that the slip was the interpreter's. This illustrates that newsworthiness requires quick reporting, and also that journalists rely on transcripts of interpreted statements for their work. In my own analyses of mass media reports on speeches and press conferences I have been able to illustrate that journalists copied the exact words as used by the interpreter, including hedges, rephrasings, and other lengthening strategies (Schäffner 2010, 2012). This is also an indication that the actual words uttered at the actual event are treated as authoritative. In other words, translation and interpreting become largely invisible in the recontextualisation processes from the actual event to the representation in the mass media. Questions of interest to Translation Studies are the following: why do journalists hardly ever indicate that the extracts they use are the result of translation and/or interpreting? Are they themselves aware that they are not copying the exact words originally spoken by the politicians?

News translation has recently seen more attention within Translation Studies. Bielsa and Bassnett's (2009) research into the role of translation in news production has revealed complex practices of news agencies. They have also shown that it is mainly the journalists themselves who perform translational tasks in producing their texts. Journalists, however, do not perceive this work to be translation. The complex practices in news translation and the interaction between translators, checkers, and editors were also addressed by Kang (2007), van Doorslaer (2009), and Chen (2011). Kang (2007) identifies news translation as a collective effort, and Chen (2011:717) argues that "commentary translation is an institutional practice performed through collaborative teamwork."

The focus so far, however, has been on textual transformations which happen in the process of translating news from one language and culture into another 
one (e.g. Valdeón 2005; Holland 2006; Kang 2007; Loupaki 2010; Gumul 2010; Chen 2011). Often using methods of Linguistics and Critical Discourse Analysis, these scholars identify strategies such as omissions, additions, neutralisation, explicitation, referential and transitivity choices, strategies of focalisation, etc. They also illustrate how such strategies mitigate or reinforce political or ideological tensions and contribute to intersubjective positioning shifts. Although they often emphasise that all these processes are influenced by ideologies and values upheld by the respective mass media institutions, comments about translators' motivations and decision taking remain speculative. For example, in discussing shifts of intersubjective positioning identified in translations from Chinese into English in Taiwanese newspapers, Chen (2011) repeatedly uses formulations such as "the translators may have supposed" or "translators may have believed". Similarly, in evaluating various English versions of a speech delivered by the President of Indonesia in British and US media, Holland (2006:235) concludes that "it is possible that there had been disagreements over its contents". Such comments show that in news translation research, too, agency is still underinvestigated.

In the research conducted by, for example, Bielsa and Bassnett (2009), Kang (2007) and Chen (2011), the translations (whether full texts or extracts) were produced within the media institutions, and either by the journalists or by professional translators. The examples which I have focused on in this article are translations or interpreters' renderings which originated within political institutions. Although these texts too are often recontextualised in the mass media (more often in shortened versions than as complete texts), they (continue to) exist within the political institutions. Whereas some political texts exist only in government offices or archives (e.g. minutes of meetings), a large number of full texts (and video recordings, which are included in the concept of text here) are made available on websites of political institutions. Although political institutions are the owners of these texts, they are thus available in the public domain. As we have seen, it is the political institutions which commission the translation of speeches and the transcription of press conferences. However, it is not always explicitly indicated that texts on websites are actually translations or transcripts of interpreters' output. The practices of the political institutions themselves are thus equally of interest to Translation Studies, raising questions such as: who provides the translations of speeches? Who decides at what time a text or transcript can be released on the website? Does any checking or proof-reading occur? If yes, who does it and what is being checked? If not, why not? These questions point to the agents who are involved in all these complex processes as the largely unknown factor in investigating the role of translation in the production, dissemination, recontextualisation, and consumption of political discourse. 
In the final section I will summarise arguments for a closer investigation of the role of translation and interpreting in political discursive events and conclude with a proposal of how this can be done.

\section{Conclusion: From political texts to contexts of political institutions}

As research in Political Linguistics and Critical Discourse Analysis has shown, political action, and thus political discourse, is very much in the public eye. Moreover, there is a close interrelationship between political institutions and mass media institutions, which is reflected in interrelations between texts. It is thus not surprising that research in Critical Discourse Analysis too has focused above all on the analysis of texts as the visible products of political interaction, and also explained communicative strategies of the political actors with reference to patterns of discursive practices such as interviews (e.g. Weizman 2008) or parliamentary discourse (e.g. Ilie 2010). Although translations have repeatedly been included in such analyses, scholars have rarely acknowledged that due attention needs to be given to this phenomenon. Chilton (2004: xii) at least refers to the crucial question of discourse analysis "across cultures, across languages and through translation" and argues that these "encounters pose more intriguing, and politically urgent, challenges for scholars in a world that is both more global and more fragmented."

The relevance of researching aspects of translation and interpreting can be summarised as follows:

- Political arguments cross linguistic, cultural, socio-political, and ideological boundaries as a result of translation and/or interpreting.

- Mediated and recontextualised discourse involves transformations and creates new relations of intertextuality across languages, discourse types, and cultures.

- In the (mediated) cross-national chain of discourse, political reality is (re)constructed and some voices of political actors are heard more frequently than others.

- Translation is embedded in institutional practices, which in turn are determined by institutional policies and ideologies.

- Translations as products reflect various conditions and constraints which research can bring to light and communicate to neighbouring disciplines (such as Critical Discourse Analysis and Political Sciences) and also to politicians, political advisors, and journalists.

Although modern Translation Studies has increasingly focused on investigating the factors that systematically govern the production, dissemination, and 
reception of texts, the translational practices in the fields of politics have not yet been sufficiently investigated (for some initial research see the contributions in Schäffner and Bassnett 2010). Discursive events in the domain of international politics, such as state visits, joint press conferences, and jointly produced policy statements, are highly complex events. As I have illustrated in this article, they are also discursive events which include translational elements: advance translations of speeches are prepared, multilingual versions of joint letters are produced, interpreting is provided at press conferences. Moreover, these discursive events and the resulting texts are recontextualised via the channels of the political institutions themselves and via mass media. As I have illustrated, translation and interpreting are frequently involved in these processes, when, for example, journalists use translations as input for their news reports. Interpreting practices are equally diverse and complex. For example, in showing extracts of the Sarkozy-Merkel press conference on its main news Tagesschau, the German TV channel ARD provided voice-over into standard German for Sarkozy. In contrast, the BBC News at Ten used two different speakers for the voice-over for both Merkel and Sarkozy, and both with very noticeable German and French accents. These practices too contribute to the way politicians are (re)presented.

The role of translation and interpreting emerges as much more complex when we look beyond the text towards the contexts, i.e. the political institutions, in which translational activities originate and are performed. The discursive events with translational elements in the domain of politics are initiated, realised, and monitored by agents, and understanding the practices and underlying policies thus requires us to research organisational structures, interactions and agency. As indicated above, the complexity of translational activities in the field of politics remains to be investigated. Moreover, this complexity has not even been questioned yet within Translation Studies. The following questions can thus be suggested as a research programme:

- Who decides which speeches by politicians get translated and into which languages? Who decides which translations are made available where (for example, on government websites or on Embassy websites)? Are any more revisions done before the final text is released? Who takes these decisions?

- Who produces (advance) translations of speeches? Who produces the different language versions of joint policy statements? Who translates press releases? Do political institutions have their own translation departments or do they outsource their translation needs?

- Who prepares transcripts of press conferences? Are they checked, amended, approved? If yes, by whom? Who authorises corrections and stylistic enhancements? 
- Who selects interpreters for state visits, interviews, and press conferences? Who decides on the form of interpreting to be chosen? Is the interpreters' performance monitored? If yes, by whom?

- What additional processes happen when interpreted speeches and interviews are turned into written reports for print media? Who are the agents in these processes?

- Do interpreters use advance translations at an actual event? If not, why not?

- In short: What actually are the translation practices in political institutions, what is their translation policy, who are the actual agents who take all these decisions?

These questions focus on the agents who have an impact on the realisation of the complex discursive events, not only the translators and interpreters as agents themselves, but above all the political actors. In my experience, political institutions such as governmental departments are very reluctant to provide information about their practices, decision making and actual agents, referring to the confidentiality of political negotiations and of political texts. As far as joint texts are concerned, one practice seems to be that politicians produce these texts themselves. This was the information which was provided to me by the Senior Press Officer of the British Foreign Secretary William Hague in respect of a joint article by Hague and his German counterpart Guido Westerwelle which was published on $15 \mathrm{Au}-$ gust 2011 in The Huffington Post (in English) and in the Frankfurter Allgemeine Zeitung (in German). These two texts, too, revealed subtle differences in their linguistic structures. The information I received also stated that "if for example our partners are proposing a first draft to us, they will normally have written it in their language before sharing an English translation with us." If politicians or political advisors perform the translations themselves, additional questions arise: Why are professional translators not involved? What do such practices tell us about the perception of translation in political institutions?

In order to find answers to the questions listed above, we need to employ ethnographic methods, such as observing actual processes, interviewing translators, interpreters and other agents involved in the institutional processes (cf. Koskinen's 2008 investigation of translation in the European Union institutions). Critical Discourse Analysis can provide concepts and methods for analysing translated texts, for identifying translation and interpreting strategies, and also for identifying transformations which happen in the processes of recontextualisation and circulation via mass media. Ethnography can be a useful accompaniment to research in both Critical Discourse Analysis and Translation Studies. In her final evaluation of advantages and shortcomings of her analysis of editorials in the French newspaper Le Monde, Le (2010) states that her text-focused analyses proved very efficient in 
describing the form, content, and function of the editorials. She adds, however, that an ethnographic study of the inner social interactions "would have allowed delving more deeply" into the issues of the editorials' legitimacy and Le Monde's identity as a news business (Le 2010:186). In a similar way, an ethnographic study of translational practices in political institutions can help us to find out if there are correlations between the textual profiles and the institutional policies and practices; and if there are, we can investigate them in more depth and also explain them with reference to underlying assumptions (including assumptions about translation), values, and ideologies. Ultimately, such research could also contribute to our understanding of the impact of translation on the reception of political discourse, of politicians, and of politics.

\section{Note}

1. The formal layout of the transcripts has been reproduced here. The references to the discursive events connected with this meeting are provided at the end of this article.

\section{References}

Baker, Mona. 2006. Translation and Conflict: A Narrative Account. New York and London: Routledge.

Baumgarten, Stefan and Chantal Gagnon. 2005. "Written Political Discourse in Translation. A Critical Discourse-Perspective on Mein Kampf". Wolfgang Thiele, Joachim Schwend and Christian Todenhagen, eds. Political Discourse: Different Media - Different Intentions New Reflections. Tübingen: Stauffenburg, 2005. 11-32. [Linguistik Band 34].

Bhatia, Aditi. 2006. "Critical discourse analysis of political press conferences". Discourse \& Society 17:2. 173-203.

Bielsa, Esperança and Susan Bassnett. 2009. Translation in Global News. London and New York: Routledge.

Blackledge, Adrian. 2005. Discourse and Power in a Multilingual World. Amsterdam-Philadelphia: John Benjamins. [Discourse Approaches to Politics, Society and Culture 15].

Boéri, Julie and Carol Maier, eds. 2010. Compromiso Social y Traducción/Interpretación - Translation/Interpreting and Social Activism. Granada: ECOS.

Calzada Pérez, Maria. 2001. "A three-level methodology for descriptive-explanatory Translation Studies". Target 13:2. 203-239.

Chen, Ya-mei. 2011. "The ideological construction of solidarity in translated newspaper commentaries: Context models and inter-subjective positioning”. Discourse é Society 22:6. 693-722.

Chilton, Paul. 2004. Analysing Political Discourse. Theory and Practice. London and New York: Routledge.

Conboy, Martin. 2007. The Language of the News. London: Routledge. 
Fairclough, Norman. 1995. Critical Discourse Analysis. London: Longman.

Fairclough, Norman. 2000. New Labour. New Language? London: Routledge.

Fairclough, Norman. 2006. Language and Globalization. London: Routledge.

Gagnon, Chantal. 2010. "When text and translation production meet: Translation in the Prime Minister's Office". Christina Schäffner and Susan Bassnett, eds. Political Discourse, Media and Translation. Newcastle upon Tyne: Cambridge Scholars Publishing, 2010. 164-177.

Gumul, Ewa. 2010. "Explicitating Political Discourse”. Christina Schäffner and Susan Bassnett, eds. Political Discourse, Media and Translation. Newcastle upon Tyne: Cambridge Scholars Publishing. 94-115.

Holland, Robert. 2006. "Language(s) in the global news: Translation, audience design and discourse (mis)representation". Target 18:2. 229-259.

Ilie, Cornelia, ed. 2010. European Parliaments under Scrutiny. Amsterdam-Philadelphia: John Benjamins. [Discourse Approaches to Politics, Society and Culture, 38].

Kang, Ji-Hae. 2007. "Recontextualization of news discourse: A case study of translation of news discourse on North Korea". The Translator 13:2. 219-242.

Koskinen, Kaisa. 2000. "Institutional Illusions: Translating in the EU Commission". The Translator 6:1. 49-65.

Koskinen, Kaisa. 2008. Translating Institutions: An ethnographic study of EU translation. Manchester: St Jerome.

Le, Elisabeth. 2010. Editorials and the Power of Media. Amsterdam-Philadelphia: John Benjamins. [Discourse Approaches to Politics, Society and Culture, 35].

Li, Juan. 2009. "Intertextuality and national identity: discourse of national conflicts in daily newspapers in the United States and China”. Discourse \& Society 20:1. 85-121.

Loupaki, Elpida. 2010. “Investigating translators's strategies in rendering ideological conflict: The case of news translation". Christina Schäffner and Susan Bassnett, eds. Political Discourse, Media and Translation. Newcastle upon Tyne: Cambridge Scholars Publishing. 55-75.

Mossop, Brian. 1990. “Translating Institution and 'Idiomatic' Translations”. Meta 35: 2. 342-354.

Okulska, Urszula and Piotr Cap, eds. 2010. Perspectives in Politics and Discourse, AmsterdamPhiladelphia: John Benjamins. [Discourse Approaches to Politics, Society and Culture, 36].

Patrona, Marianna. 2011. "Neutralism revisited: When journalists set new rules in political news discourse". Mats Ekström and Marianna Patrona, eds. Talking Politics in Broadcast Media. Amsterdam-Philadelphia: John Benjamins, 2011. [Discourse Approaches to Politics, Society and Culture, 42].

Rundle, Christopher and Kate Sturge, 2010. eds. Translation under Fascism. Basingstoke: Palgrave Macmillan.

Schäffner, Christina. 2010. "Political communication: Mediated by Translation". Urszula Okulska and Piotr Cap, eds. Perspectives in Politics and Discourse, Amsterdam-Philadelphia: John Benjamins. 255-278 [Discourse Approaches to Politics, Society and Culture, 36].

Schäffner, Christina. 2012. "Press conferences and recontextualisation". Alonso Araguas Iciar, Jesus Baigorri Jalon and Helen L. Campbell, eds. Ensayos Sobre Traduccion Juridica e Institucional, Granada: Comares. 69-83.

Schäffner, Christina and Susan Bassnett, eds. 2010. Political Discourse, Media and Translation. Newcastle upon Tyne: Cambridge Scholars Publishing.

Valdeón, Roberto A. 2005. “The CNNenEspañol News”. Perspectives 13:4. 255-267.

van Doorslaer, Luc. 2009. "How language and (non-)translation impact on media newsrooms. The case of newspapers in Belgium”. Perspectives 17:2. 83-92. 
Weizman, Elda. 2008. Positioning in Media Dialogue. Amsterdam-Philadelphia: John Benjamins. [Dialogue Studies, 3.].

Weiss, Gilbert and Ruth Wodak, eds. 2003. Critical Discourse Analysis. Theory and Disciplinarity. London: Palgrave Macmillan.

Wodak, Ruth and Paul Chilton, eds. 2005. A New Agenda in (Critical) Discourse Analysis: Theory, Methodology and Interdisciplinarity. Amsterdam-Philadelphia: John Benjamins [Discourse Approaches to Politics, Society and Culture, 13].

\section{Texts analysed}

(1) Joint French-German letter to Herman Van Rompuy

http://www.bundesregierung.de/Content/DE/Pressemitteilungen/BPA/2011/08/2011-08-17dt-franz-brief-rompuy.html?nn $=430028$

http://www.bundesregierung.de/Content/DE/_Anlagen/2011/08/2011-08-17-dt-franz-briefeng.pdf?_blob=publicationFile

http://www.bundesregierung.de/Content/DE/_Anlagen/2011/08/2011-08-17-dt-franz-brieffranz.pdf?_blob=publicationFile

(2) Palais de l'Elysée - Mardi 16 août 2011

http://www.elysee.fr/president/les-actualites/conferences-de-presse/2011/conference-de-presse-franco-allemande.11870.html

(3) Pressekonferenz von Bundeskanzlerin Merkel und dem französischen Staatspräsidenten Sarkozy

Dienstag, 16. August 2011

http://www.bundesregierung.de/Content/DE/Mitschrift/Pressekonferenzen/2011/08/2011-0816-pk-merkel-sarkozy-paris.html? $\mathrm{nn}=430000$

\section{Author's address}

Christina Schaeffner

Professor of Translation Studies

School of Languages and Social Sciences

Aston University

Aston Triangle

BIRMINGHAM

B4 7ET

UK

c.schaeffner@aston.ac.uk 